Review of Palaeobotany and Palynology, 42 (1984): 23-44

Elsevier Science Publishers B.V., Amsterdam - Printed in The Netherlands

The Northwest European Pollen Flora, 31

\title{
CANNABACEAE, MORACEAE AND URTICACEAE
}

\author{
W. PUNT and MARIEKE MALOTAUX
}

Laboratory of Palaeobotany and Palynology, State University, Utrecht (The Netherlands)

\section{LITERATURE}

Accorsi and Mazzanti (1980), Bassett et al. (1974), Erdtman (1943, 1952, 1959), Erdtman et al. (1961), Hyde and Adams (1958), Kuprianova (1965), Migal (1969), Miyoshi (1983), Moore and Webb (1978), Nilsson et al. (1977), Sorsa and Huttunen (1975), Tarnavaschi et al. (1967), Tsukada (1964), Van Zant et al. (1979), Van Zinderen Bakker (1953), Wodehouse (1935).

\section{INTRODUCTION}

Although this is not the procedure followed in most of the contributions to the Northwest European Pollen Flora, this part combines three families. The reason for this is the close resemblance of the pollen grains in these three families that often makes identification of the pollen a problem. It is of practical importance to have similar pollen types combined into a single key and considerations of this kind also led to the amalgamation of the families Sparganiaceae and Typhaceae (Punt, 1975).

In Northwest Europe the family Urticaceae is represented by five species in two genera. The Cannabaceae comprises two genera each with a single species while the Moraceae has one genus and two species.

Pollen grains of the three families often show a thickening around the porus margin. It is, however, difficult to decide whether this is caused by a thickening of the nexine (costa) or of the sexine (annulus). Various authors have used different terms for this phenomenon. Sorsa and Huttunen (1975) chose the term "annulus", whereas Birks (1973) used "costa" and Hyde and Adams (1958) "aspis", a term introduced by Wodehouse (1935). For practical reasons we have chosen to use the term annulus for all pollen types.

As in the "Plantaginaceae" (Clarke and Jones, 1977), the outermost layer of the ornamentation (sexine 3 ) consists of processes that are rounded at their top rather than spine-like. Moreover, they are smaller than $1 \mu \mathrm{m}$. The term scabrae has therefore been used. These scabrae are sometimes also discernable in L-O analysis, but mostly only in SEM.

Another difficult feature to see is the distinction between the nexine and sexine (sexine 1 or sexine 2 ). The differentiation is especially poor in silicone 
oil and the separation of the layers is often invisible. On the other hand, with $\mathrm{L}-\mathrm{O}$ analysis the scabrae are often more easily seen in silicone oil than in glycerine jelly.

The literature on pollen morphology in these families is very extensive. The best paper on the Urticaceae is that by Sorsa and Huttunen (1975) which, although solely illustrated by SEM pictures, is based on LM observations, and LM descriptions are given in the text and in tables. Discussion of their results is given here under the comment on the relevant types. The most significant paper on the recognition of Cannabis pollen is that of Godwin (1967) in which the section on the separation of Humulus lupulus (pollen) and that of Cannabis sativa is the work of Dr. D.M. Churchill of Cambridge. Most of the finds of Cannabis pollen in peat deposits that have been recorded since 1967 have been based on this paper. Because of its economic importance Cannabis pollen has often been the subject of pollenmorphological studies (e.g. Makino and Melhem, 1973; Migal, 1969), but these authors gave statistical results only and pure morphological differences are scarcely given.

Humulus lupulus is a native European plant growing as a climber often in alder fen-woods, but also in hedges and thickets. There are pollen records from peat of the Holocene period (Godwin, 1975) and from Pleistocene cores (e.g. Zagwijn, 1973). Cannabis was introduced from Central Asia into Greece and Italy in classical times. It subsequently spread and was distributed throughout Europe before the birth of Christ (Godwin, 1967).

Urticaceae pollen has been recorded from the Pleistocene period onwards (e.g. Andersen, 1961; Zagwijn, 1973; Godwin, 1975).

\section{SPECIMENS EXAMINED}

\section{Cannabaceae}

Cannabis sativa L. - Belgium: Kramer 1622 (U); England: Lousley s.n. (BM); France: Maboge s.n. (U); The Netherlands: Ankersmit 4 (U), Buysman 23 (U), Cult. Cantons Park 53-1051 (U), 56-2145 (U), Swart 1826 (U); Switzerland : Müller s.n. (U).

Humulus lupulus L. - England: Pocock s.n. (BM); France: Florschütz s.n. (U); Germany: Hekking 3597(U); The Netherlands: Arnolds 1229 (U), Dercksen s.n. (U), Leeuwenberg 625 (U), Mennega 655 (U); Sweden: Löfrander 52 (UPS).

\section{Moraceae}

Morus alba L. - Austria: Kramer and Westra 4151 (U), Behrendsen s.n. (U); Italy: Rostan s.n. (L); Jugoslavia: Ferman and Hille 261 (U); Japan: Maximowicxz s.n. (L); The Netherlands: Cult. Cantons Park 5600 (U).

M. nigra L. - The Netherlands: Herb. Lako s.n. (L), Van Slooten s.n. (U), Cult. Hortus s.c. and s.n. (U).

\section{Urticaceae}

Parietaria judaica L. - England: Exc. Stud. Biol. Utrecht 68-379 (U); Ireland: Exc. Stud. Biol. Utrecht 71-56 (U); The Netherlands: Arnolds 1628 (U).

$P$. officinalis L. - Belgium: Lejeune and Courtois 211 (U); Germany: Scheppig 8.n. (U); The Netherlands: Zijlstra s.n. (U), Fresh material Verhoeven, Anno 1954. 
Urtica dioica L. - Belgium: Schoenmakers 303 (U); England: Macer-Wright s.n. (BM); Ireland: Hessel, Klein and Rubers 834 (U); The Netherlands: Oudemans 1098 (U), Fresh material Rem, Anno 1952, Fresh material Punt, Anno 1958; Sweden: Mohner s.n. (UPS).

U. pilulifera L. - France: Hekking 592 (U), Exc. Stud. Biol. Utrecht 56-518 (U), Exc. Stud. Biol. Utrecht 56-581 (U).

$U$. urens L. - Germany : Behrendsen s.n. (U); England: Howard 1111 (U); Iceland: Ferman and Hille 152 (U); The Netherlands: Arendsen-Hein s.n. (U), Fresh material Punt, Anno 1958, 1961, 1965.

\section{KEY TO THE POLLEN TYPES}

1. a. Number of pori 6 to 10, usually ca. 8, pantoporate. Exine thin, not differentiated into nexine and sexine. Circular pores a little protruding, with a narrow annulus $\ldots \ldots \ldots \ldots \ldots$........ Urtica pilulifera type

b. Number of pori less, usually 2 or 3 , sometimes 4 or 5 and rarely with 6 pores, but then exine and pores different $\ldots \ldots \ldots \ldots \ldots \ldots 2$

2. a. Pori distinctly protruding in optical section, annulus broad and distinct .......................... Humulus lupulus type

b. Pori not or only slightly protruding, annulus narrow or absent ....3

3. a. Pori slightly or not protruding, circular in outline, small (diameter 1-2.5 $\mu \mathrm{m})$; grains small (E 13-20 $\mu \mathrm{m}) \ldots \ldots$. Urtica dioica type

b. Pori not protruding, usually irregularly elliptic, rather large (diameter 2.5-5 $\mu \mathrm{m})$; grains rather large (E 18-37 $\mu \mathrm{m}) \ldots \ldots$ Morus alba type

Humulus hupulus type (Plates I, II)

Pollen class: (2-) 3 (-4)-Zonoporate.

$P / E$ ratio: Semitransverse to subtransverse.

Apertures: Ectoaperture - porus, more or less circular, to a little elliptic or rhombic-elliptic in Humulus, distinctly protruding; margins distinct; distinct annulus; operculum absent. Endoaperture - porus, of the same size and outline as ectoaperture or a little smaller; distinctly margined; no distinct costae. Exine: Not particularly thin. The differentiation between nexine and sexine usually apparent except in Cannabis. Exine distinctly thicker around the porus (annulus), but it is not clear if the sexine or the nexine is thickened. Columellae not visible in LM. In Humulus surface more or less verrucate, in Cannabis scabrae superposed on a more or less smooth tectum. Scabrae spine-like but apices a little blunt.

Ornamentation: Psilate in LM, scabrate in SEM, the scabrae densely arranged. Scabrae sometimes vaguely visible in $\mathrm{L}-\mathrm{O}$ analysis and Phase contrast.

Outlines: Equatorial view - elliptic. Polar view - circular with protruding pores.

Measurements: Glycerine jelly - P 18.0-27.0 $\mu \mathrm{m}$; E 20.0-30.0 $\mu \mathrm{m} ; \mathrm{P} / \mathrm{E}$ ratio 0.77-0.96. Exine 1.5-2.0 $\mu \mathrm{m}$. Porus diameter 2-3 $\mu \mathrm{m}$. Silicone oil $\mathrm{P} 18-28.0 \mu \mathrm{m} ; \mathrm{E} 19.0-29.0 \mu \mathrm{m} ; \mathrm{P} / \mathrm{E}$ ratio $0.75-0.98$. 


\begin{tabular}{llll}
\hline & $\begin{array}{l}\mathrm{P} \\
(\mu \mathrm{m})\end{array}$ & $\begin{array}{l}\mathrm{E} \\
(\mu \mathrm{m})\end{array}$ & P/E ratio \\
\hline $\begin{array}{l}\text { Humulus lupulus } \\
\text { Glycerine jelly }\end{array}$ & $18.0-(20.0)-23.0$ & $20.0-(23.5)-27.0$ & $0.77-(0.93)-0.96$ \\
$\begin{array}{l}\text { Silicone oil } \\
\text { Cannabis sativa }\end{array}$ & $18.0-(20.5)-25.0$ & $19.0-(22.5)-25.0$ & $0.75-(0.91)-0.98$ \\
$\begin{array}{l}\text { Glycerine jelly } \\
\text { Silicone oil }\end{array}$ & $21.0-(24.5)-26.5$ & $24.5-(27.0)-30.0$ & $0.83-(0.89)-0.95$ \\
& $21.0-(23.0)-28.0$ & $23.0-(26.0)-29.0$ & $0.83-(0.88)-0.98$ \\
\hline
\end{tabular}

Species: Cannabis sativa, Humulus lupulus.

Differences in morphological characteristics

Humulus lupulus Cannabis sativa

\section{Porus}

a. Outline more or less elliptic or rhombic

b. With $400 \times$ no direct rim around porus in surface view

c. Maximum diameter of porus greater than width of annulus

d. In optical section no internal annulus or void between sexine and nexine

Exine

a. Tectum at the annulus usually rises in a shallow slope above the genera level of the outer wall

b. Nexine/sexine separation often visible

Ornamentation

In SEM more or less verrucate

Size

Usually amaller than in Cannabis, E 19-(23)-27 $\mu \mathrm{m}$ circular or regular elliptic

with $400 \times$ a distinct rim between annulus and porus (see Plate, 3 )

maximum diameter of porus less than or equal to width of annulus in optical section rim of the porus forming a hollow internal annulus or void between sexine and nexine

tectum at the annulus rises steeply above the general surface

nexine/sexine separation not visible

in SEM surface smooth

usually larger than in Humulus, E 21-26)-30 $\mu \mathrm{m}$

\section{Comments}

Wodehouse (1935), Erdtman et al. (1961, 1963), Faegri and Iversen (1975), Moore and Webb (1978) and many other authors give no characteristics to differentiate between Humulus and Cannabis pollen, and it is true that the pollen of these two genera is very similar. Distinct morphological differences are few and often difficult to interpret. Nevertheless, a number of differential characteristics do exist:

(1) The most constant characteristic is found in the ultrafine ornamentation. With SEM the scabrae of Humulus pollen appear to be irregularly distributed; they are grouped together on broad, shallowly raised areas, thus giving the surface a slightly verrucate appearance. The scabrae of Cannabis 
pollen are not grouped but distributed singly over a smooth surface (Plate I, 1-3). Unfortunately this characteristic ornamentation is not visible in LM.

Differentiation with LM is far less easy and is best accomplished with a combination of characters most of which are to be found in the porus.

(2) In Cannabis pollen with $400 \times$ magnification the margin of the porus usually appears as a rim between porus and annulus (Plate II, 3), whereas this phenomenon is absent in Humulus. This characteristic is based on a particular refraction phenomenon in the light microscope, the exact nature of which has not been explained.

(3) Less convincing is the difference in the ratio of porus diameter to annulus width. Usually the porus is larger than the width of the annulus in Humulus and smaller or equal in Cannabis pollen, but many examples may be found in which the situation is unclear.

(4) Still less reliable is the outline of the porus. In Humulus it is elongated and often a little rhombic (Plate II, 5), whereas Cannabis pollen has circular, or slightly elliptic pores. Although not consistently present, when it is there, this character is reliable for identification.

(5) Sometimes, as an additional character to the above, the internal annulus or void described by Churchill (Godwin, 1967) may be of use, but this is another character that is not consistently present.

(6) The slope of the tectum towards the annulus is another feature proposed by Churchill (Godwin, 1967), but in a few cases the feature may be of use.

(7) A character that is difficult to use, but probably fairly constant is the vival distinction between nexine and sexine. This is clearer in Humulus than in Cannabis.

(8) Most unreliable of all is the size of the grains. In general, Humulus pollen is smaller than Cannabis pollen, but the overlap is considerable. According to the size measurements we have made, based on a restricted number of specimens, if $\mathrm{E}<23 \mu \mathrm{m}$, then the pollen is most probably Humulus and if $\mathrm{E}>27 \mu \mathrm{m}$ it belongs to Cannabis. From the present results it is clear, however, that most of the pollen grains in the Humulus-Cannabis complex are between 23 and $27 \mu \mathrm{m}$.

Man's association with Cannabis goes far back into history. Hemp was already reported in classical times and it is therefore quite natural that many cultivated races with a concomitantly large variation in pollen size should exist (Migal, 1969; Makino and Melhem, 1973). Apart from this, both these papers mention that monoecious races produce pollen grains that are significantly smaller in the statistical sense than those of normally dioecious plants. Moreover, Migal noted that in monoecious races there is variation in the number of pores. Three- and four-pored pollen are in the majority, but two 2-pored grains sometimes occur. Other authors (Erdtman et al., 1961; Kuprianova and Alyoshina, 1972) also described Cannabis as having 2-4pored pollen grains. In our material only 3 -pored grains occur.

Humulus pollen is also sometimes 4-pored, but much less frequently and, 
as in Cannabis, our material was exclusively 3-pored. This is in distinct contrast to our results in the Moraceae and Urticaceae where there is a much larger variation in pore number.

Morus alba type (Plates III, IV , 1-5)

Pollen class: $2-4(-5,6,7)$-Zonoporate, sometimes pantoporate.

$P / E$ ratio: Semitransverse to subtransverse (in 3-4-porate grains).

Apertures: Ecto- and endoaperture similar in size and outline (congruent); usually more or less elliptic or sometimes circular in outline with irregular margins, not or little sunken, not protruding; operculum may be present; narrow annulus present, distinct in $M$. nigra and less distinct in $M$. alba. Pores not always equidistantly spaced. Operculum present, but often lost during acetolysis.

Exine: Thin. Exine not clearly differentiated into nexine and sexine, columellae not visible even at high magnification. Sexine 3 not distinguishable in cross-section.

Ornamentation: Scabrate. Scabrae visible with high magnification or phasecontrast. In SEM scabrae irregularly and rather sparsely distributed over the surface; surface not exactly smooth, scabrae usually acute (micro-echinae).

Outlines: Equatorial view - elliptic. Polar view - circular, elliptic, often more or less irregular angular.

Measurements: Glycerine jelly - P 16.0-28.0 $\mu \mathrm{m} ; \mathrm{E} 19.0-37.0 \mu \mathrm{m} ; \mathrm{P} / \mathrm{E}$ ratio $0.72-0.97$. Exine 1.0-2.0 $\mu \mathrm{m}$. Porus diameter $2.5-5.0 \mu \mathrm{m}$. Silicone oil - P 16.0-28.0 $\mu \mathrm{m} ; \mathrm{E} 18.0-37.0 \mu \mathrm{m} ; \mathrm{P} / \mathrm{E}$ ratio $0.67-0.94$.

\begin{tabular}{|c|c|c|c|}
\hline & $\begin{array}{l}\mathbf{P} \\
(\mu \mathrm{m})\end{array}$ & $\begin{array}{l}\mathbf{E} \\
(\mu \mathrm{m})\end{array}$ & $\mathrm{P} / \mathrm{E}$ ratio \\
\hline $\begin{array}{l}\text { Morus alba } \\
\text { Glycerine jelly } \\
\text { Silicone oil }\end{array}$ & $\begin{array}{l}16.0-(19.0)-22.0 \\
16.0-(19.0)-21.0\end{array}$ & $\begin{array}{l}19.0-(21.0)-25.0 \\
18.0-(22.5)-24.0\end{array}$ & $\begin{array}{l}0.81-(0.88)-0.90 \\
0.76-(0.87)-0.90\end{array}$ \\
\hline $\begin{array}{l}\text { Morus nigra } \\
\text { Glycerine jelly } \\
\text { Silicone oil }\end{array}$ & $\begin{array}{l}22.0-(26.0)-28.0 \\
23.0-(25.5)-28.0\end{array}$ & $\begin{array}{l}27.0-(32.0)-37.0 \\
28.0-(31.5)-37.0\end{array}$ & $\begin{array}{l}0.72-(0.81)-0.90 \\
0.67-(0.80)-0.89\end{array}$ \\
\hline
\end{tabular}

Species: Morus alba, M. nigra.

Key to the species

1. a. Number of pores usually 2 , less frequently 3 ; size rather small (E 18$26 \mu \mathrm{m}$ ); outline usually regularly elliptic in equatorial view; pores equidistant from one another ......................

b. Number of pores usually $3-4$, less frequently 2 or 5 ; size rather large (E 26.0-37.0 $\mu \mathrm{m}$ ); outline often more or less irregularly angular and pores not always equidistant from one another ........ Morus nigra 


\section{Comment}

Morus pollen has rarely been described. The best descriptions of both the Northwest European species are given by Kuprianova (1965) and her descriptions are in accordance with the present ones.

As in most Urticaceae species, the number of pores is rather variable (see Table I), but in most specimens of Morus alba diporate pollen grains are in the majority whereas in specimens of Morus nigra 3-4-porate pollen grains are most frequent.

Urtica dioica type (Plates IV, 6-7, V, VI)

Pollen class: (2-)3-4(-5)-Zonoporate, occasionally 4-5-pantoporate.

$P / E$ ratio: Subtransverse to semitransverse.

Apertures: Ecto- and endoaperture similar in size and outline, more or less circular, protruding a little in Urtica, not protruding or very slightly sunken in Parietaria; margins distinct; a narrow annulus visible in Urtica, but absent in Parietaria; exine slightly thickened around the porus in Urtica; operculum small, but usually lost during acetolyses.

Exine: Thin, a little thicker around the porus. No visible differentiation of exine layers in LM. Columellae not discernable in cross-section.

Ornamentation: Psilate or vaguely scabrate in LM. Scabrae distinct in phasecontrast and SEM.

Outlines: Equatorial view - elliptic. Polar view - circular or slightly angular in Urtica species, but not in Parietaria species.

Measurements: Glycerine jelly - P 11.5-17.5 $\mu \mathrm{m}$; E 13-20 $\mu \mathrm{m} ; \mathrm{P} / \mathrm{E}$ ratio $0.74-0.99$. Exine $0.5-1.5 \mu \mathrm{m}$. Porus diameter $1.0-2.5 \mu \mathrm{m}$. Silicone oil $\mathrm{P}$ 11.5-17.5 $\mu \mathrm{m} ; \mathrm{E}$ 12.5-19.0 $\mu \mathrm{m} ; \mathrm{P} / \mathrm{E}$ ratio $0.74-0.99$.

\begin{tabular}{|c|c|c|c|}
\hline & $\begin{array}{l}\mathbf{P} \\
(\mu \mathrm{m})\end{array}$ & $\begin{array}{l}\mathrm{E} \\
(\mu \mathrm{m})\end{array}$ & $\mathrm{P} / \mathrm{E}$ ratio \\
\hline $\begin{array}{l}\text { Parietaria judaica } \\
\text { Glycerine jelly } \\
\text { Silicone oil }\end{array}$ & $\begin{array}{l}13.0-(15.5)-16.5 \\
13.0-(14.5)-17.0\end{array}$ & $\begin{array}{l}15.0-(17.0)-19.5 \\
14.5-(16.5)-19.0\end{array}$ & $\begin{array}{l}0.83-(0.91)-0.97 \\
0.84-(0.90)-0.95\end{array}$ \\
\hline $\begin{array}{l}\text { Parietaria officinalis } \\
\text { Glycerine jelly } \\
\text { Silicone oil }\end{array}$ & $\begin{array}{l}11.5-(13.5)-15.5 \\
11.5-(13.0)-15.0\end{array}$ & $\begin{array}{l}13.0-(15.0)-18.0 \\
12.5-(14.5)-16.5\end{array}$ & $\begin{array}{l}0.83-(0.89)-0.93 \\
0.85-(0.91)-0.99\end{array}$ \\
\hline $\begin{array}{l}\text { Urtica dioica } \\
\text { Glycerine jelly } \\
\text { Silicone oil }\end{array}$ & $\begin{array}{l}12.5-(15.0)-16.5 \\
13.0-(15.5)-17.5\end{array}$ & $\begin{array}{l}14.0-(17.5)-19.0 \\
16.0-(17.5)-19.0\end{array}$ & $\begin{array}{l}0.74-(0.85)-0.99 \\
0.74-(0.88)-0.99\end{array}$ \\
\hline $\begin{array}{l}\text { Urtica urens } \\
\text { Glycerine jelly } \\
\text { Silicone oil }\end{array}$ & $\begin{array}{l}13.0-(15.0)-16.5 \\
12.0-(15.0)-16.5\end{array}$ & $\begin{array}{l}14.5-(17.0)-20.0 \\
14.0-(17.0)-19.0\end{array}$ & $\begin{array}{l}0.79-(0.88)-0.95 \\
0.80-(0.88)-0.95\end{array}$ \\
\hline
\end{tabular}

Species: Parietaria judaica, P. officinalis, Urtica dioica, U. urens. 


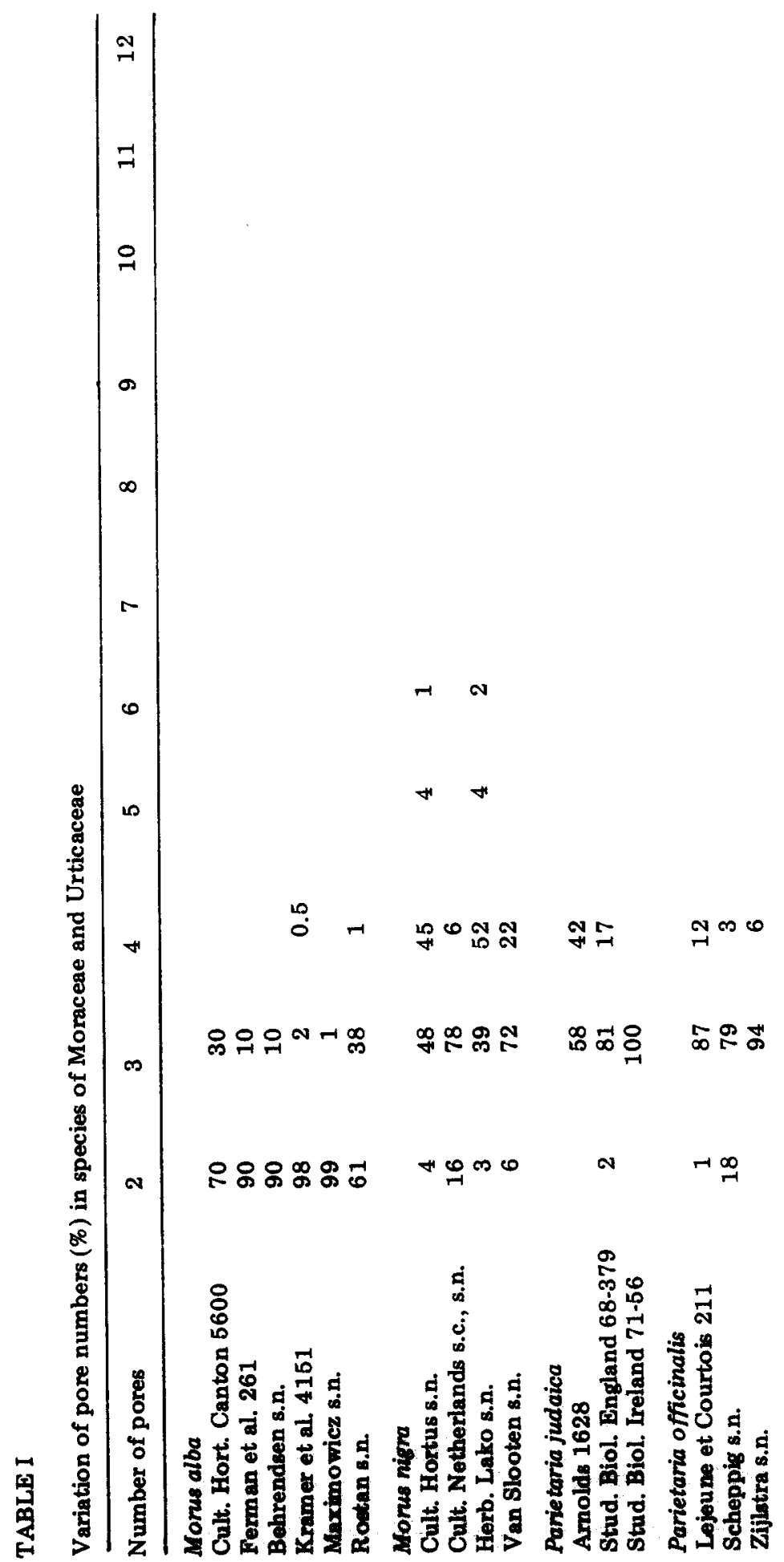




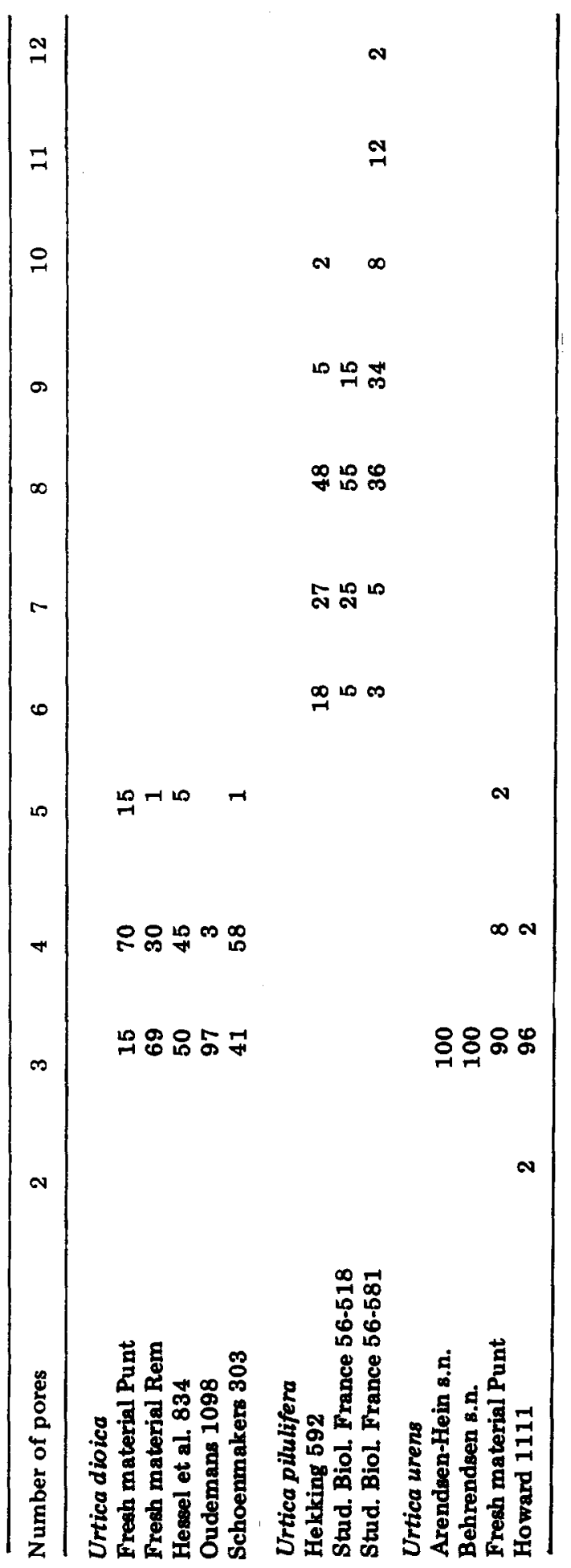


Key to the species

1. a. Exine around porus thickened, margins a little protruding .......2

b. Exine not thickened around porus, margins not protruding, sometimes a little sunken . . . . . . . . . . . . . . . . . Parietaria judaica

Parietaria officinalis

2. a. Scabrae regularly distributed in L-O analysis and with phase-contrast. In SEM scabrae narrow at base not tapering ........... Urtica urens

b. Scabrae irregularly distributed in L-O analysis and with phase-contrast, in SEM scabrae sharply tapering, broad at base ....... Urtica dioica

\section{Comments}

Parietaria and Urtica pollen grains can easily be separated from each other by two characteristics: (1) the annulus is slightly protruding in Urtica but does not protrude, or may even not be distinguishable in Parietaria; $(2)$ the ornamentation of Parietaria pollen is slightly coarser than that of Urtica in LM.

Within the genera, the species are less easily recognized with a light-microscope. In Parietaria the two species can only be separated on size. The scabrae are quite identical and give no clue for a separation of the species. The only difference between the two species is in the size but this is not consistent. Most $P$. officinalis grains are a little smaller in diameter than those of $P$. judaica.

The species of Urtica, on the other hand, may be distinguished with the use of high-magnification objectives. It has long been recognized that using phase-contrast it is possible to separate Urtica dioica and U. urens (e.g. Krog, 1954; Andersen, 1961; Faegri and Iversen, 1975; Sorsa and Huttunen, 1975). The distribution of the scabrae is characteristic for each species. In $U$. dioica the distribution is irregular and usually the shape of the scabrae is conical with a sharp apex and broad base; these bases are contiguous. In $U$. urens the scabrae are more regularly distributed and the shape of them is baculoid with a blunt apex and small base. There is distinct space between the bases. Of course, these characteristics are best seen in SEM, but the distribution is certainly also visible with high magnification in LM. Another difference may be found in the number of pores. In $U$. urens the majority of the pollen grains are 3-pored, whereas in $U$. dioica many 4-pored, and even 5-pored, pollen grains occur.

Faegri and Iversen (1975) suggested that pollen of Parietaria can be separated from that of Urtica by an irregular margin in optical section. We could not confirm this because the character appeared to be inconstant. It has therefore not been used in the key as better differential characters are available (see Key to the species). Sorsa and Huttunen (1975) described Urtica urens grains as goniotreme but, although some pollen grains appear to be slightly angular in polar view, too many are perfectly circular to make this characteristic useful. Moreover, slightly angular pollen grains also occur in $U$. dioica. 
Special attention has been paid to the number of apertures. The pore number is variable in most specimens which is clearly demonstrated in Table I. Especially U. dioica pollen shows much variation, but most other species also have pollen grains with a variable number of pores.

Accorsi and Mazzanti (1980) described the two Parietaria species as well, and they reported the following morphological differences: (1) $P$. judaica is significantly smaller than $P$. officinalis. Their measurements, however, show a considerable overlap; (2) there is a difference in density and shape of the scabrae in SEM micrographs. As all observations are based on one specimen of each species little is known about the variation. Our own results based on several more specimens do show infraspecific variation in the density and shape of the scabrae. Therefore, it seems that neither size nor the shape of the scabrae allow a reliable differentiation between the two species on pollen-morphological data as Accorsi and Mazzanti suggested.

\section{Urtica pilulifera type (Plate VII)}

Pollen class: 6-12, usually 7-9-pantoporate.

Shape: Ellipsoid.

Apertures: Ecto- and endoaperture similar in size and outline, more or less circular, a little protruding; margins distinct; narrow annulus present; operculum absent; sometimes a few granules present on the porus membrane.

Exine: Thin, a little thicker around the porus. Exine not obviously differentiated into nexine and sexine. Columellae not discernable in cross-section.

Ornamentation: Psilate in LM, scabrate in SEM. Scabrae regularly distributed, short, conical, but with a small base; much space inbetween the scabrae.

Outlines: Elliptic or circular.

Measurements: Glycerine jelly - longest axis 24-(30)-35 $\mu \mathrm{m}$. Silicone oil longest axis 24-(28)-34 $\mu \mathrm{m}$. Exine ca. 1.5 $\mu \mathrm{m}$. Porus diameter 2-2.5 $\mu \mathrm{m}$. Species: Urtica pilulifera.

\section{Comments}

The scabrae of $U$. pilulifera resemble those of $U$. urens. They are also regularly distributed and have small bases. They are, however, not baculoid, but more or less conical. The type is, of course, mainly characterized by the large number of pores. In Western Europe $U$. pilulifera is the only species with more than five pores, but Sorsa and Huttunen (1975) reported that $U$. pentandra, an Asiatic species, also has many pores. 
Plate descriptions (all plates $\times 2000$ except where otherwise stated)

\author{
PLATE I (p. 35)
}

Cannabis sativa L. (figs.1-3, Müller s.n.)

1. Scanning electron micrograph; polar view.

2. Scanning electron micrograph; equatorial view, porus more or less circular.

3. Scanning electron micrograph; ornamentation ( $x 10000)$.

Humulus lupulus L. (figs.4-6, Hekking 3597)

4. Scanning electron micrograph; ornamentation ( $\times 10000)$.

5. Scanning electron micrograph; polar view.

6. Scanning electron micrograph; equatorial view, porus elliptic in outline.

PLATE II (p. 36)

Cannabis sativa L. (figs.1-2, 4, Kramer 1622; fig.3, Buysman 23)

1. Polar view; cross-section; hollow internal annulus or void visible, annulus rises steeply above the general surface.

2. Equatorial view; cross-section.

3. Porus; distinct rim between annulus and porus (black).

4. Porus; maximum diameter of porus less than width of annulus.

Humulus lupulus L. (figs.5-6, Hekking 3597; figs.7-8, Arnolds 1229)

5. Polar view; cross-section; internal void absent.

6. Porus; outline elliptic, maximum diameter greater than width of annulus.

7. Porus; no direct rim between annulus and porus.

8. Porus; outline elliptic and no direct rim around porus.

PLATE III (p. 37)

Morus alba L. (figs.1-2, Kramer and Westra 4151)

1. Scanning electron micrograph; mesoporium.

2. Scanning electron micrograph; porus $(x 10000)$.

Morus nigra L. (figs.3-5, Cult. Hortus s.c., s.n.)

3. Scanning electron micrograph; 3-porate pollen grain, asymmetric.

4. Scanning electron micrograph; 4-porate pollen grain, more or less symmetric.

5. Scanning electron micrograph; ornamentation $(x 10000)$.

PLATE IV (p. 38)

Morus alba L. (figs.1-2, Cult. Hortus Canton s.n.)

1. Polar view; cross-section.

2. Equatorial view; cross-section.

Morus nigra L. (figs.3-5, Cult. Hortus s.c., s.n.)

3. Polar view; cross-section.

4. Porus; irregular rim, more or less circular in outline.

5. Porus; rim more or less regular, outline elliptic.

Parietaria judaica L. (figs.6-7, Exc. Stud. Biol. Utrecht, England 1968-379)

6. Equatorial view; cross-section, margins around porus not thickened.

7. Polar view; cross-section, pori a little sunken. 
PLATE I (Humulus lupulus type: Cannabis sativa 1-3, Humulus lupulus 46)
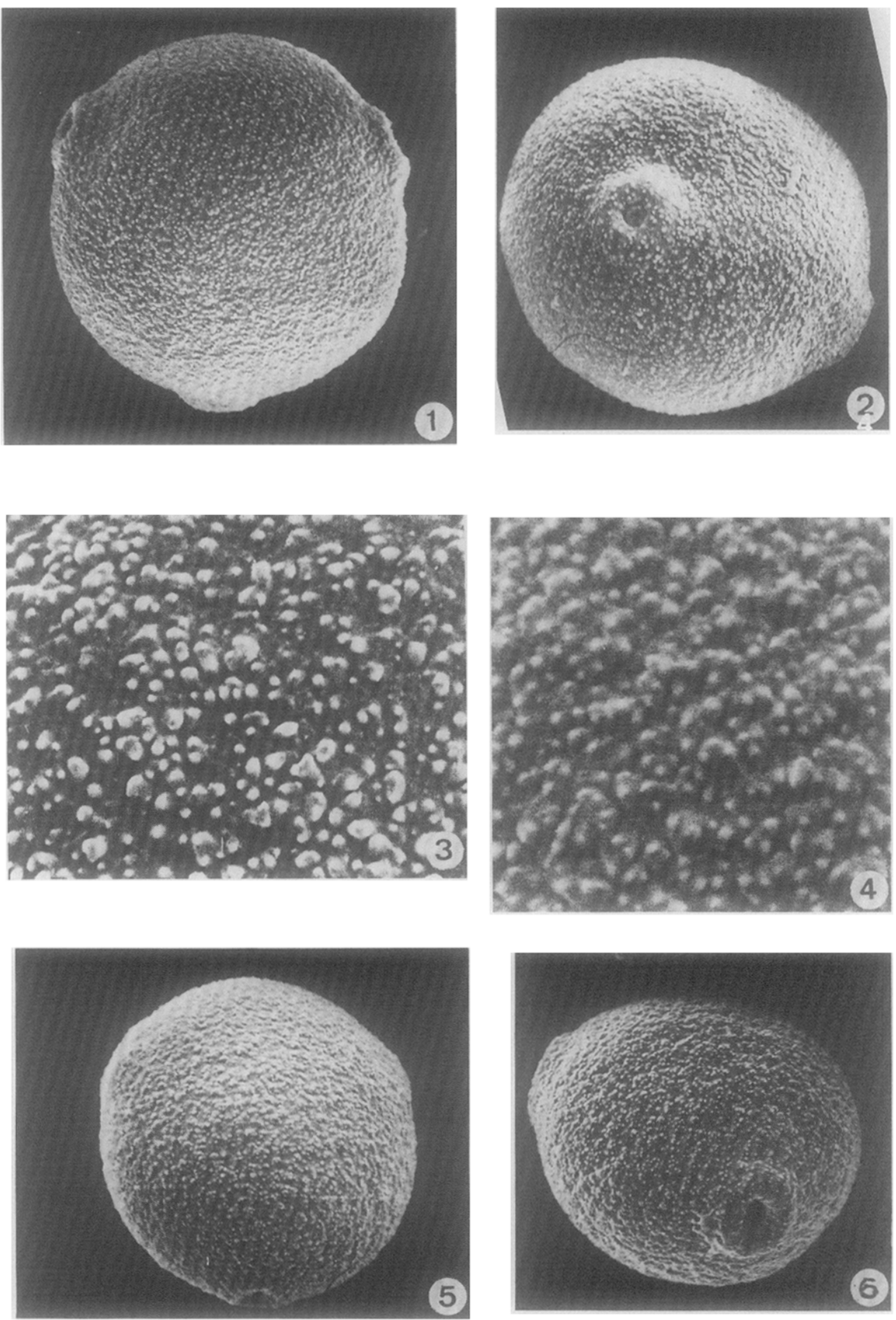
PLATE II (Humulus lupulus type: Cannabis sativa 1-4, Humulus lupulus $5-8)$
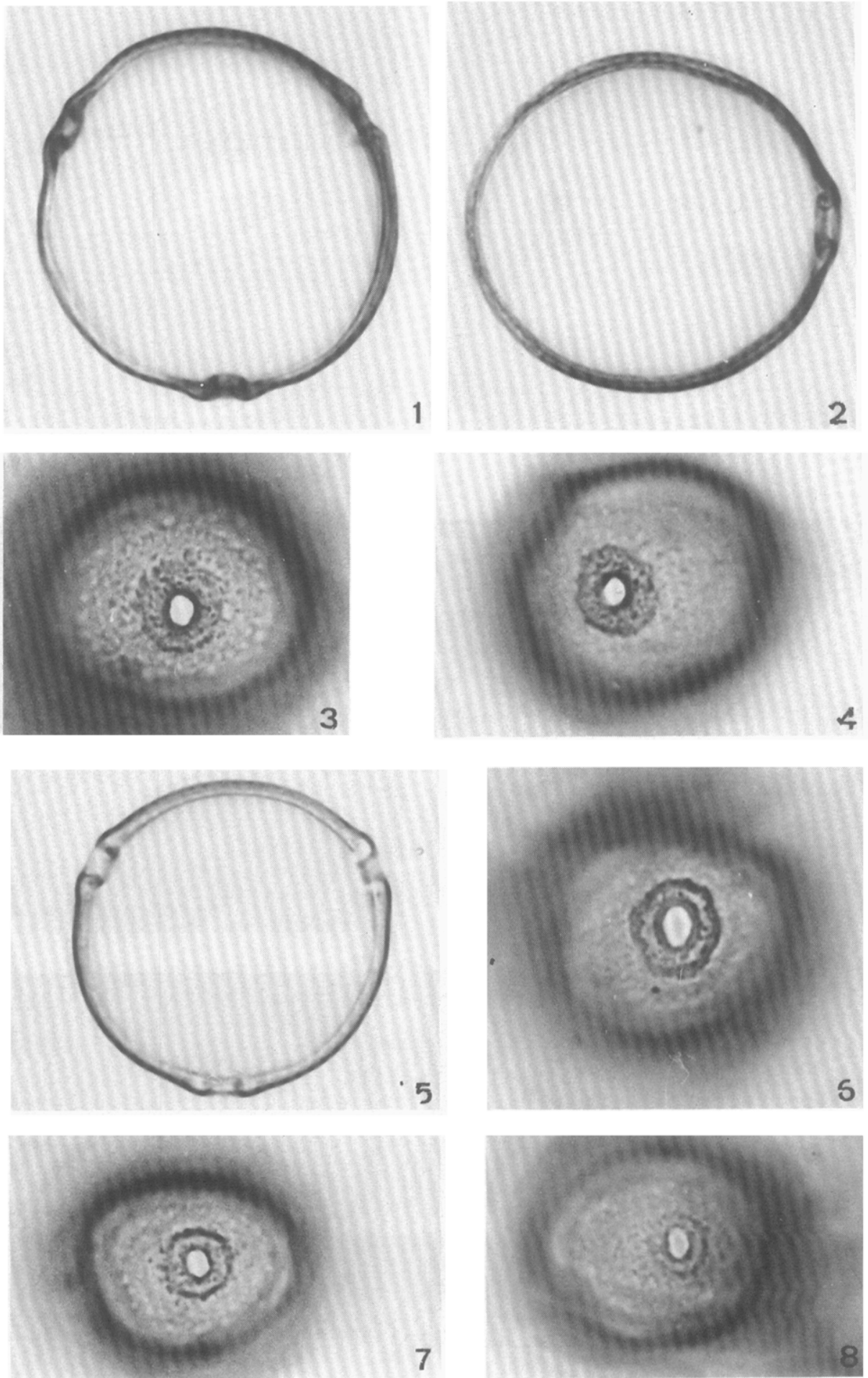


\section{PLATE III (Morus alba type: M. alba 1-2, M. nigra 3-5)}
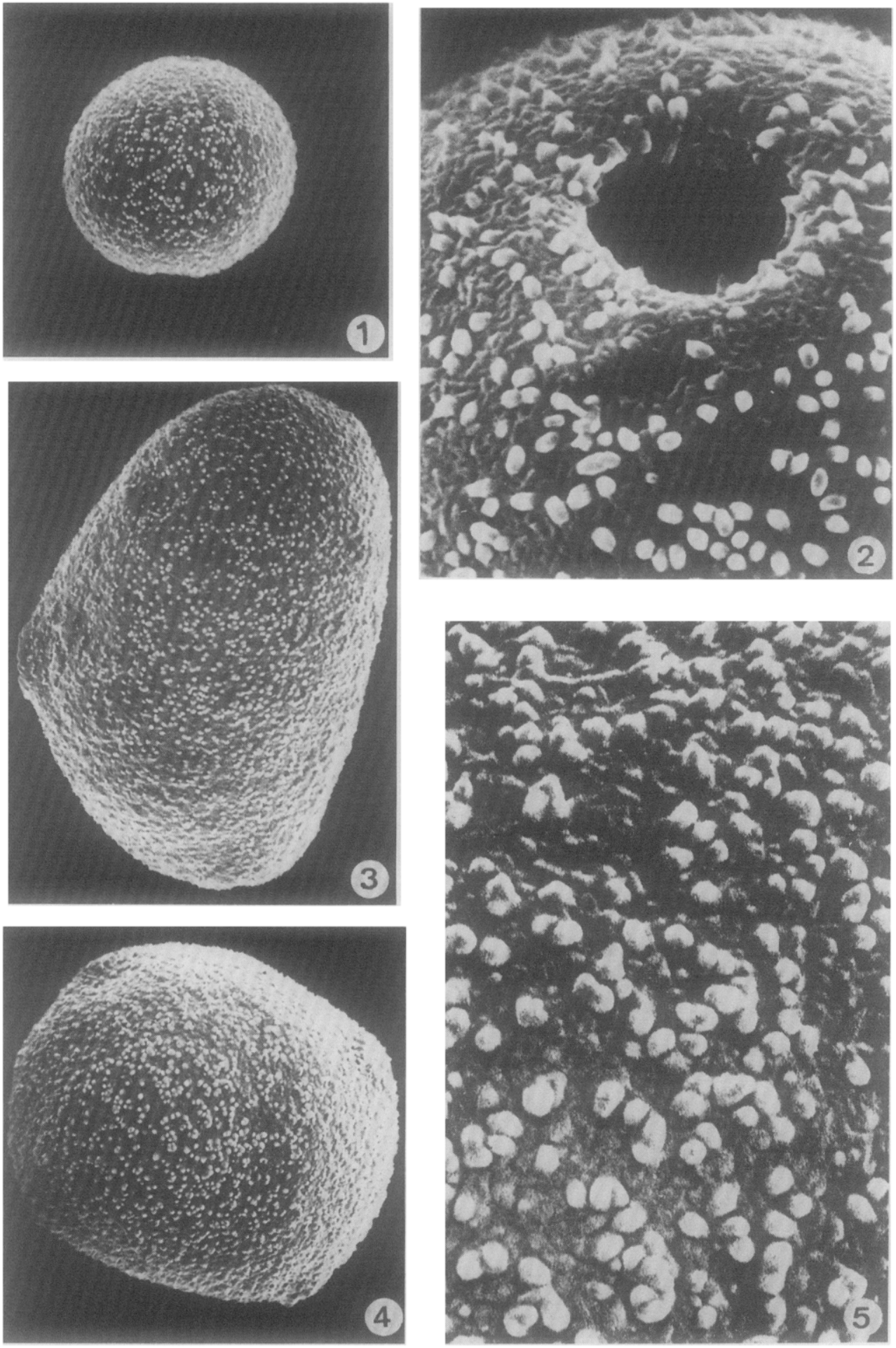
PLATE IV (Morus alba type: $M$. alba 1-2, M. nigra 3-5; Urtica dioica type Parietaria judaica)

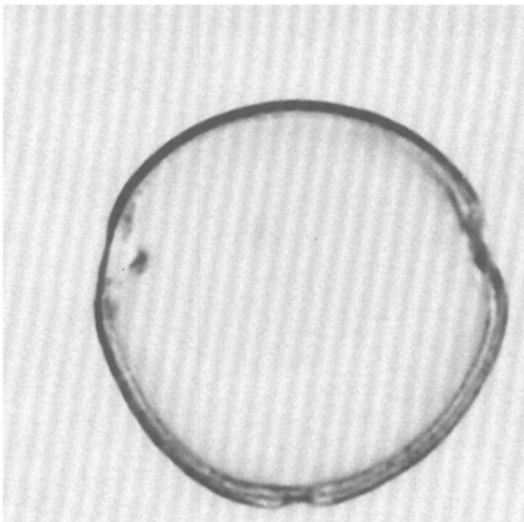

1
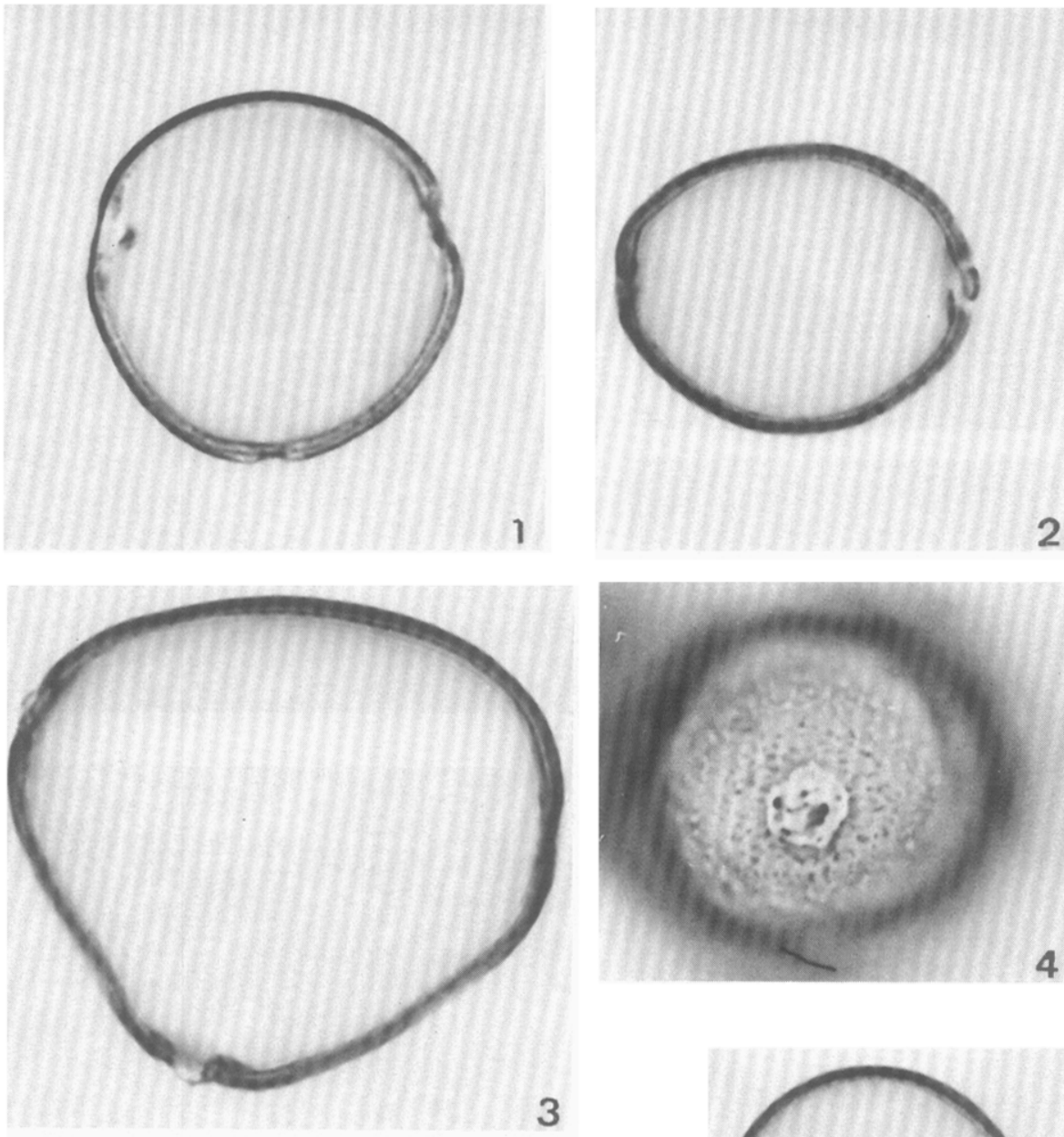

3
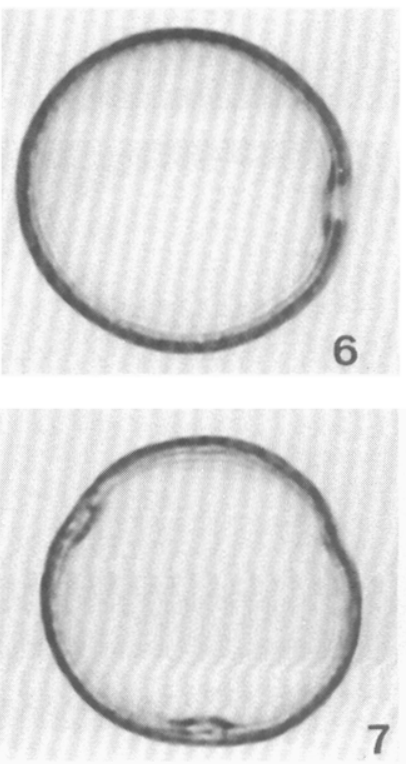
PLATE V (Urtica dioica type: Parietaria judaica 1-2, 8-9, P. officinalis 3-7)
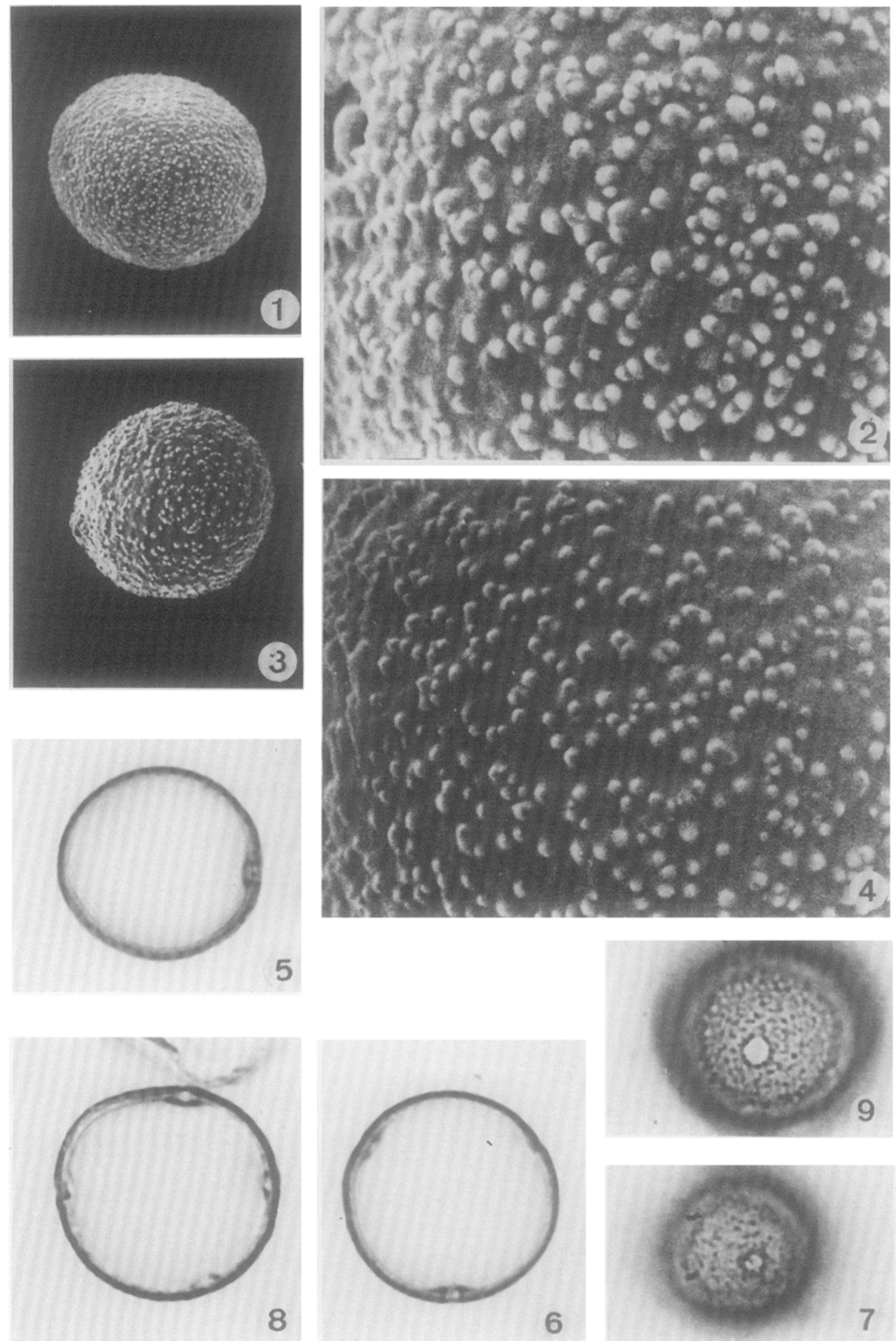

6 
PLATE V (p. 39)

Parietaria judaica L. (figs.1-2, 9, Exc. Stud. Biol. Utrecht, England 1968-379; fig.8, Arnolds 1628)

1. Scanning electron micrograph; equatorial view of 4-pored pollen grain, two pores visible.

2. Scanning electron micrograph; ornamentation, a faint porus visible ( $\times 10000)$.

8. Polar view; cross-section of a 4-pored pollen grain, margins of pori not protruding.

9. Porus; circular outline, no annulus visible.

Parietaria officinalis L. (figs.3-4, Scheppig s.n.; figs.6-7, Lejeune et Courtois 211)

3. Scanning electron micrograph; polar view.

4. Scanning electron micrograph; ornamentation $(\times 10000)$.

5. Equatorial view; cross-section of a 3-porate pollen grain.

6. Polar view; cross-section, pori a little sunken.

7. Porus; circular outline, rather diffuse.

\section{PLATE VI (p. 41)}

Urtica urens L. (figs.1-2, Howard 1111; figs.5-7, Behrendsen s.n.)

1. Scanning electron micrograph; polar view.

2. Scanning electron micrograph; ornamentation, more or less regular ( $\times 10000)$.

5. Equatorial view; cross-section.

6. Porus; circular outline with narrow, but distinct annulus.

7. Polar view; cross-section, pori a little protruding.

Urtica dioica L. (figs.3-4, Hessel, Klein and Rubers 834; figs.8-10, Schoenmaker 303)

3. Scanning electron micrograph; polar view.

4. Scanning electron micrograph; ornamentation, irregular $(\times 10000)$.

8. Polar view; cross-section of 3-pored pollen grain.

9. Polar view; cross-section of 4-pored pollen grain, margins around pori protruding.

10. Equatorial view; cross-section, porus margin thickened.

\section{PLATE VII (p. 42)}

Urtica pilulifera L. (figs.1-5, Exc. Stud. Biol. Utrecht, France 1956-581)

1. Scanning electron micrograph; overall view.

2. Scanning electron micrograph; ornamentation and porus $(\times 10000)$.

3. Cross-section; granule on the porus membrane.

4. Porus; circular outline with a narrow, but distinct annulus.

5. Cross-section; pori with distinct annuli. 
PLATE VI (Urtica dioica type: U. urens 1-2, 5-7, U. dioica 3-4, 8-10)
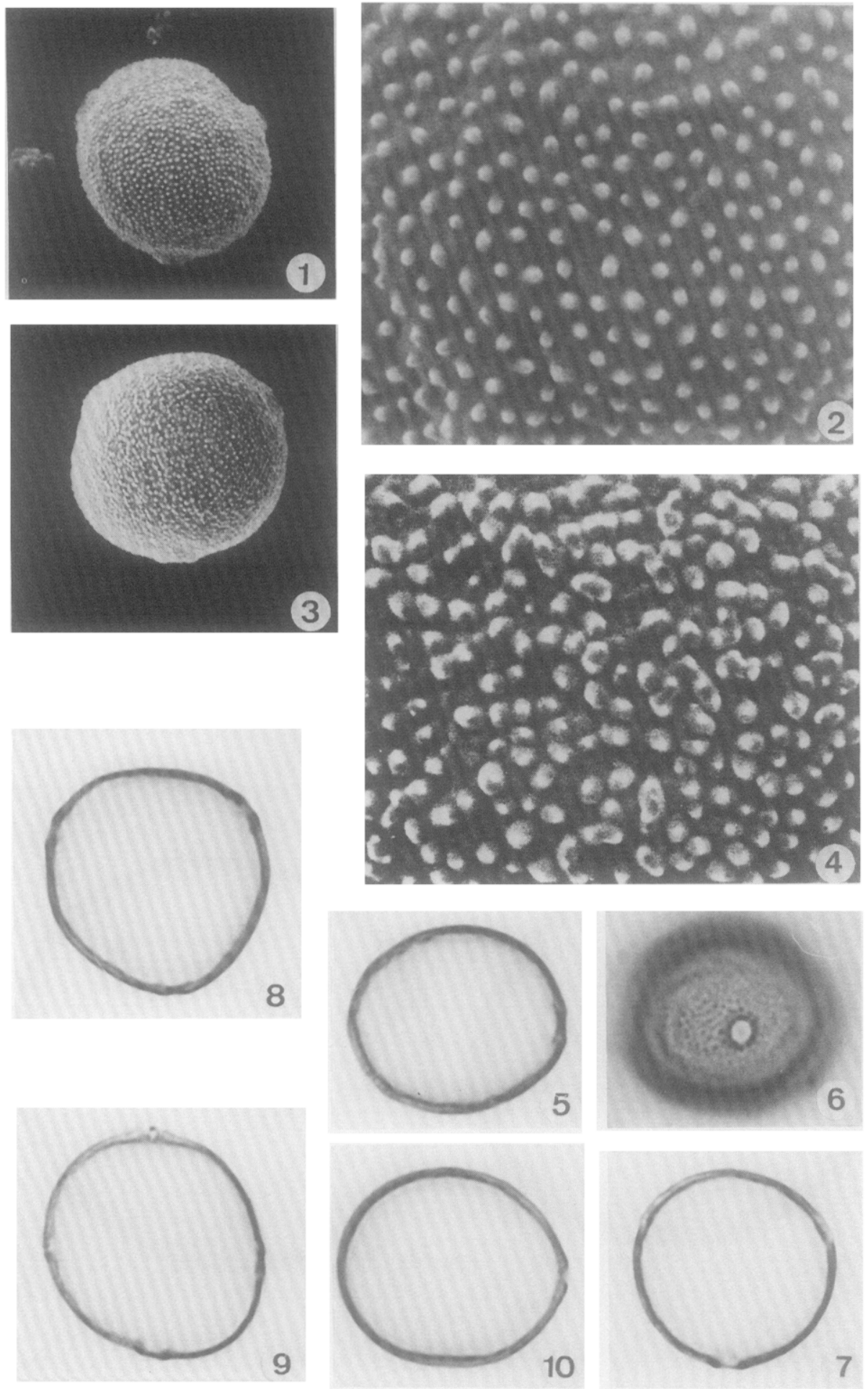
PLATE VII (Urtica pilulifera type: U. pilulifera)
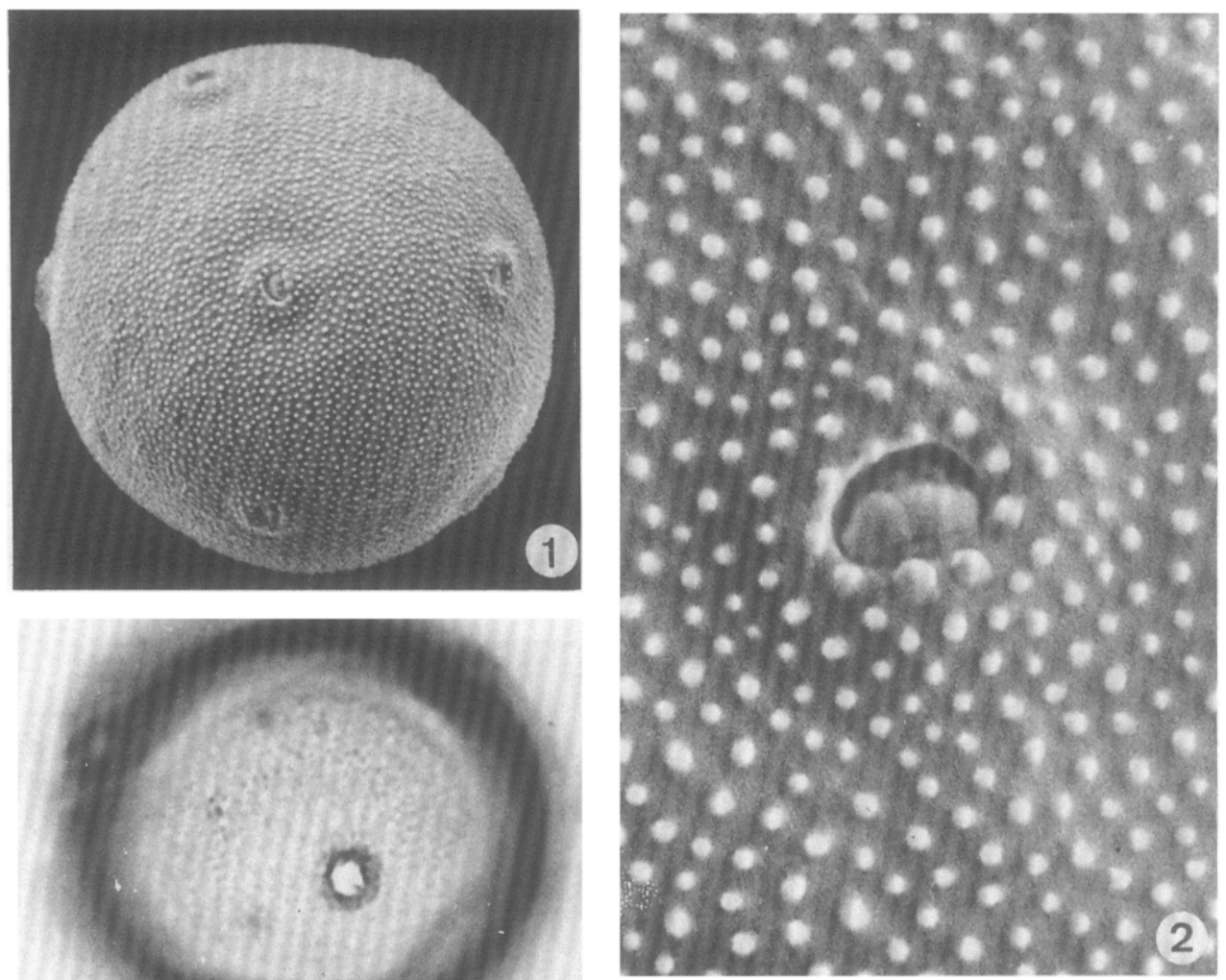

3
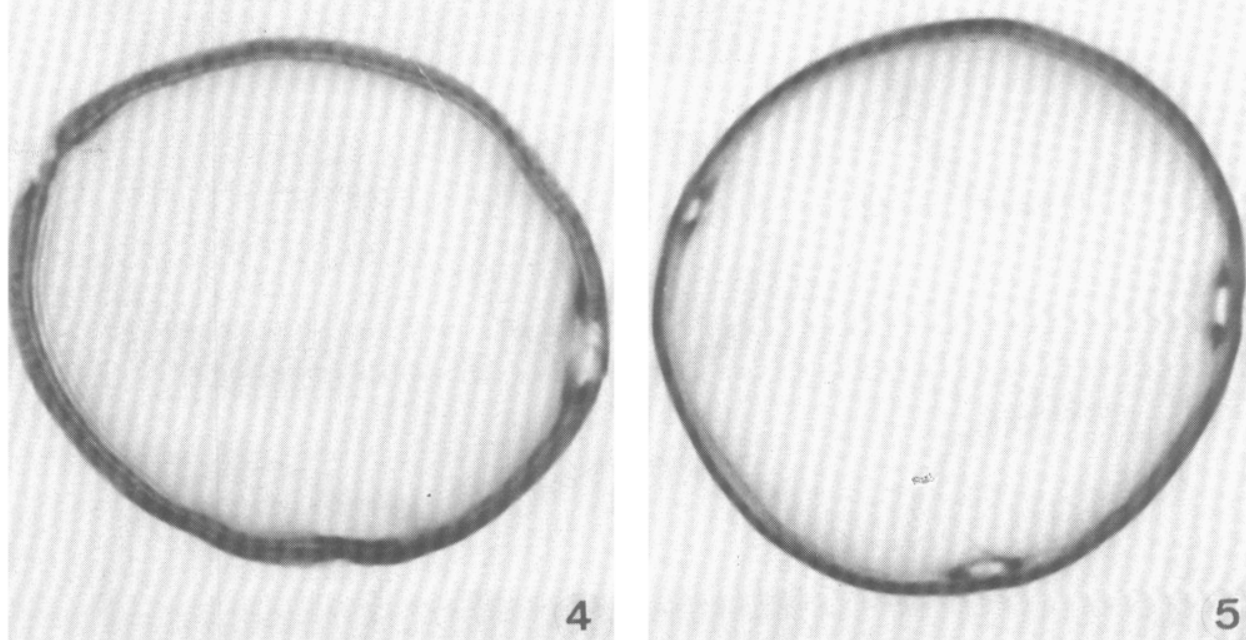


\section{REFERENCES}

Accorsi, A.A. and Mazzanti, M.B., 1980. Studi sui pollini alergogeni. Parietaria officinalis L. en $P$. judaica L.: posizione sistematica, morfologia e biometrica del polline. Webbia, $34: 643-661$.

Andersen, S.Th., 1961. Vegetation and its environment in Denmark in the Early Weichselian (last glacial). Dan. Geol. Unders., II, 75: 1-75.

Bassett, I.J., Crompton, C.W. and Woodland, D.W., 1974. The family Urticaceae in Canada. Can. J. Bot., 52: 503-516.

Birks, H.J.B., 1973. Past and Present of the Isle of Skye. A Palaeoecological Study. Cambridge University Press, Cambridge $415 \mathrm{pp}$.

Clarke, G.C.S. and Jones, M.R., 1977. The Northwest European Pollen Flora, 15. Plantaginaceae. Rev. Palaeobot. Palynol., 24: NEPF 129-154.

Erdtman, G., 1943. An Introduction to Pollen Analysis. Chronica Botanica Co., Waltham, MA, 239 pp.

Erdtman, G., 1952. Pollen Morphology and Plant Taxonomy. Angiosperms. Almqvist and Wiksell, Stockholm, 539 pp. (Urticaceae, pp.445-446).

Erdtman, G., 1959. UV micrographs and photomicrographs from the palynological laboratory, Stockholm-Solna. Grana Palynol., 2(1): 36-39.

Erdtman, G., 1966. Pollen Morphology and Plant Taxonomy - Angiosperms. Hafner, New York, NY, 2nd ed., 553 pp.

Erdtman, G., Berglund, B. and Praglowski, J., 1961. An Introduction to a Scandinavian Pollen Flora, I. Almqvist and Wiksell, Stockholm, 92 pp.

Erdtman, G., Praglowski, J. and Nilsson, S., 1963. An Introduction to a Scandinavian Pollen Flora, II. Almqvist and Wiksell, Stockholm, 89 pp.

Faegri, K. and Iversen, J., 1975. Textbook of Pollen Analysis. Munksgaard, Copenhagen, 3rd ed., $295 \mathrm{pp}$.

Godwin, H., 1967. Pollen-analytical evidence for the cultivation of Cannabis in England. Rev. Palaeobot. Palynol., $4: 71-80$.

Godwin, H., 1975. History of the British Flora. Cambridge University Press, Cambridge, 2nd ed., $541 \mathrm{pp}$.

Hyde, H.A. and Adams, K.F., 1958. An Atlas of Airborne Pollen Grains. MacMillan, London, 112 pp.

Krog, H., 1954. In: J. Iversen, Studies in Vegetational History. Pollen analytical investigations of a $\mathrm{C}^{14}$-dated Alleröd section from Ruds Vedby. Dan. Geol. Unders, II. Raekke, No. $80: 120-139$.

Kuprianova, L.A., 1965. The Palynology of the Amentiferae. Bot. Inst. Komarov Akad. Nauk. S.S.S.R., Leningrad, 215 pp.

Kuprianova, L.A. and Alyoshina, L.H., 1972. Pollen and Spores of Plants from the Flora of European Part of the U.S.S.R. Bot. Inst. Komarov, Akad. Nauk S.S.S.R., Leningrad, $171 \mathrm{pp}$.

Migal, N.D., 1969. On the morphology of hemp (Cannabis L.) pollen. Bot. Zh., 54: 274276.

Makino, H. and Melhem, T.S., 1973. O polen de Cannabis sativa L. Cienc. Cult., 25: 535538.

Miyoshi, N., 1983. Pollen morphology by means of Scanning Electron Microscope. 6. Urticales. Bull. Hiruzen Res. Inst. Okayama Univ. Sci., 8: 41-53.

Moore, P.D. and Webb, J.A., 1978. An Mlustrated Guide to Pollen Analysis. Hodder and Stoughton, London, 133 pp.

Nilsson, S., Praglowski, J. and Nilsson, L., 1977. Atlas of airborme pollen grains and spores in Northern Europe. Ljungföretagen, Örebrö, 159 pp.

Punt, W., 1975. The Northwest European Pollen Flora, 5. Sparganiaceae and Typhaceae. Rev. Palaeobot. Palynol., 19: NEPF 75-88.

Sorsa, P. and Huttunen, P., 1975. On the pollen morphology of the Urticaceae. Ann. Bot. Fenn., 12: 165-182. 
Tarnavschi, I.T., Şerbănescu-Jitariu, G., Mitroiu, N. and Radulescu, D., 1967. Zur Pollenmorphologie der Urticales aus der Flora Rumäniens. Rev. Roum. Biol. Sér. Bot., 12: $251-262$.

Tsukada, M., 1964. Pollenmorphology and identification, III. Modern and fossil tropical pollen with emphasis on Bombacaceae. Pollen Spores, $6: 393-462$.

Van Zant, K.L., Webb III, T., Peterson, G.M. and Baker, R.G., 1979. Increased Cannabis/ Humulus pollen, an indicator of European agriculture in Iowa. Palynology, 3: 227233.

Van Zinderen Bakker, E.M., 1953. South African Pollen Grains and Spores, Part I. A.A. Balkema, Rotterdam, Cape Town, 88 pp.

Wodehouse, R.P., 1935. Pollen grains. McGraw-Hill, New York, NY, 574 pp.

Wodehouse, R.P., 1971. Hayfever plants. Hafner, New York, NY, 2nd ed., 280 pp.

Zagwijn, W.H., 1973. Pollenanalytical studies of Holsteinian and Saalian beds in the Northern Netherlands. Meded. Rijksgeol. Dienst, N.S., 24: 139-156. 